\title{
Standardization of Suitable Treatment for Sucker Production of Malbhog (AAB) Banana through Macropropagation
}

\author{
Dorodi P. Duarah ${ }^{1 *}$, Subhanakar Saha ${ }^{1}$, D.N. Hazarika ${ }^{2}$, \\ Supriya Langthasa ${ }^{2}$ and Rupshree Borah ${ }^{2}$
}

${ }^{I}$ Department of Horticulture, Assam Agricultural University, Jorhat-785013, Assam, India

${ }^{2}$ B. N. College of Agriculture, Assam Agricultural University,

Biswanath Chariali - 784176, Assam, India

*Corresponding author

\begin{tabular}{|l|}
\hline Ke y w o r d s \\
$\begin{array}{l}\text { Treatments, BAP, } \\
\text { Trichoderma viride, } \\
\text { Malbhog, } \\
\text { Macropropagation, } \\
\text { Regeneration }\end{array}$ \\
\hline Article Info \\
\hline $\begin{array}{l}\text { Accepted: } \\
\text { 26 April } 2018 \\
\text { Available Online: } \\
10 \text { May } 2018\end{array}$ \\
\hline
\end{tabular}

\section{Introduction}

Banana is an important fruit crop and considered as cash crop providing food security, nutrition and income for many small farmers. Banana having a great extensive uses, religious and economic values in India including Assam, its whole plant is utilized for worship, culinary and table purposes. Despite of its economic importance, banana production faces major challenges including scarcity of high quality planting materials, attack of insect pests and diseases. Demand for pest free and high quality planting materials has been on the increase in Assam. Naturally regenerated suckers preferred by the 
farmers are more likely to carry pests and diseases leading to reduce productivity and a short lifetime of new plantations (Faturoti et al., 2002). Commercial cultivation of banana is greatly hindered by various biotic and abiotic factors (Seshu Reddy et al., 1999), which include scarcity of high quality planting materials, diseases and pests, lack of agricultural inputs and limited land space for farming. Farmers mostly rely on natural regeneration of existing plants for propagation (Faturoti et al., 2002).

Tissue Culture (TC) is one of the available propagation methods that produce planting materials free from diseases and pests, with genetic purity and uniform growth (Sheela and Ramachandran, 2001). However, adoption has been low due to high capital investment and subsequent high cost of suckers. This has led to the plantlets being too expensive for majority of the small holders to acquire.

\section{Materials and Methods}

\section{Preparation of planting materials}

Four to five months old uniform size suckers of Malbhog banana were collected from disease free plantation of nearby areas. The average weight of corms ranged from 400 $500 \mathrm{~g}$. The corms were cleaned by removing the roots and detopped just above the junction of corm and pseudostem. The roots of the suckers were trimmed and surface of the corms were scrapped well with sharp knife. All the suckers were decapitated by cutting the pseudostem just above the corm. The corms were dipped in 0.3 per cent Bavistin solution for 30 minutes and after taking out, they were allowed to dry in shade for a day. The apical meristem of each corm was removed by scooping out to a depth of $2 \mathrm{~cm}$ for making a cavity of $2 \mathrm{~cm}$ in diameter and corm was given 4 - 6 cross wise cuts to avoid the water stagnation. Four decorticated rhizomes were planted in each treatment as per technical programme at a gap of $1 \mathrm{~m}$.

\section{Preparation of IBA solution}

The corms under treatment $\mathrm{T}_{9}$ were dipped in a bucket containing 0.25 per cent IBA solution (2.5 g IBA per litre of water) for 30 minutes prior to planting in the pits.

\section{Preparation of BAP solution}

BAP solution of 0.04 per cent was prepared by mixing $40 \mathrm{mg}$ BAP powder with sodium Hydroxide Pallets (1 - 2 pieces) and 1 - 2 drops of ethanol for removing the residual effect and added 1 litre of water. Four $\mathrm{ml}$ of 0.04 per cent BAP solution was poured into the meristematic cavity of each corms planted under treatments of $\mathrm{T}_{4}(0.04 \% \mathrm{BAP}), \mathrm{T}_{5}(0.04$ $\%$ BAP $+30 \mathrm{~g}$ Enriched Compost) and $\mathrm{T}_{6}(30$ $\mathrm{g}$ Trichoderma viride $+0.04 \% \mathrm{BAP}+30 \mathrm{~g}$ Enriched Compost).

\section{Preparation of $\mathrm{GA}_{3}$ solution}

$\mathrm{GA}_{3}$ solution of $50 \mathrm{ppm}$ was prepared by dissolving $50 \mathrm{mg} \mathrm{GA} 3$ powder in 1 litre of water. Five $\mathrm{ml}$ of $50 \mathrm{ppm} \mathrm{GA}_{3}$ solution was poured into meristematic cavity of each corm planted under treatment $\mathrm{T}_{8}$.

\section{Preparation of enriched compost}

Enriched compost was prepared by mixing 17 $\mathrm{kg}$ Rock Phosphate with PSB (1 kg) and Azospirillum (1 $\mathrm{kg}$ ) in $100 \mathrm{~kg}$ of vermicompost. Enriched compost @ 30 g per pit was applied before planting of corm.

\section{Decapitation of primary and secondary suckers}

The primary suckers were decapitated by removing the growing points and 4 - 6 horizontal cuts were given for the young corm 
to produce secondary suckers thereby producing tertiary suckers. The tertiary suckers which developed 3-4 numbers of leaves were separated from the mother corm carefully causing minimum damage to the roots. The corms with roots of the separated tertiary plantlets were dipped into the Bavistin solutions $(0.3 \%)$ for 30 minutes. The treated tertiary suckers were transplanted in the polybags having $5-6$ pierced holes $(15 \mathrm{~cm} \mathrm{x}$ $20 \mathrm{~cm}$ size) at the bottom and lower sides of the polybags. The growing medium for filling of polybags were prepared by mixing soil and decomposed cow dung at the ratio of 1: 1 and $1 \mathrm{~kg}$ 'Bioveer' containing Trichoderma viride per quintal of growing medium was mixed. Light irrigation was done in polybags immediately after transplanting to settle down the media. The transplanted plantlets were kept under shade in net house (50\% shade) for hardening, i.e., for establishment of the plantlets. The media in the polybags were kept in moist condition by light irrigation as and when necessary. The suckers were hardened for 3 months ( 90 days) prior to transplanting in the main field. Observations on vegetative characters of suckers were recorded at 15 days interval during hardening.

\section{Results and Discussion}

The data generated during experimentation in field were statistically analyzed by Randomized Block Design (RBD). Significance and non-significance of the variance due to different treatments were determined by calculating the respective ' $\mathrm{F}$ ' values using Microsoft Excel (MS Office ver. 2007) and ' $F$ ' values as the method described by Panse and Sukhatme, (1985).

Significant effects due to different treatments were observed on production of primary suckers. Among the different treatments, the corms treated with BAP and Trichoderma viride $\left(\mathrm{T}_{3}\right)$ produced the highest (3.07) number of primary suckers followed by 2.94 recorded at $\mathrm{T}_{4}$ (BAP). However, there were no significant differences in production of primary suckers between the treatments, viz., $\mathrm{T}_{2}, \mathrm{~T}_{3}, \mathrm{~T}_{4}$ and $\mathrm{T}_{5}$. The corms treated with $\mathrm{GA}_{3}$ $\left(\mathrm{T}_{8}\right)$ produced the lowest number of primary suckers (1.0) which was significantly different from all other treatments. The highest production of secondary suckers (5.73) was recorded in $\mathrm{T}_{3}$ (BAP + Trichoderma viride) which differed significantly from the rest of the treatments. Production of secondary suckers in $\mathrm{T}_{4}$ (BAP) was 4.82 which were at par with 4.53 recorded in $\mathrm{T}_{5}$ (BAP+ Enriched Compost). The corms treated with BAP with Trichoderma viride $\left(\mathrm{T}_{3}\right)$ produced the highest (18.94) number of tertiary suckers followed by 18.40 in $\mathrm{T}_{4}$ (BAP) and both of them differed significantly from the rest of the treatments. IBA treated corms $\left(\mathrm{T}_{9}\right)$ produced 16.94 number of tertiary suckers followed by 16.76 in $\mathrm{T}_{10}$ (Nitrogen) and they were at par with each other (Table 1).

The longest pseudostem $(17.17 \mathrm{~cm})$ was recorded in at the end of hardening period $\left(90^{\text {th }}\right.$ day) average maximum height of tertiary suckers became $35.67 \mathrm{~cm}$ in $\mathrm{T}_{8}\left(\mathrm{GA}_{3}\right)$ which was different significantly from the rest of the treatments. The shortest pseudostem (17.17 $\mathrm{cm}$ ) was recorded in $\mathrm{T}_{4}$ (BAP) followed by $17.60 \mathrm{~cm}$ in $\mathrm{T}_{5}(\mathrm{BAP}+$ Enriched Compost $)$ and $17.61 \mathrm{~cm}$ in $\mathrm{T}_{7}$ (Azospirillum + PSB) and they were at par with each other. There was no significant differences in pseudostem height between $\mathrm{T}_{9}$ (IBA) and $\mathrm{T}_{10}$ (Nitrogen); and between $\mathrm{T}_{1}$ (control), $\mathrm{T}_{2}$ (Trichoderma viride) and $\mathrm{T}_{6}$ (Trichoderma viride $+\mathrm{BAP}+$ Enriched Compost) (Table 1). Number of leaves per sucker increased gradually from the beginning to the end of the hardening period. $\mathrm{T}_{4}(0.04 \%$ BAP) recorded the highest (5.87) number of the functional leaves and it was at par with 5.77 in $\mathrm{T}_{5}$ (BAP + Enriched Compost) and both the treatments differed significantly from rest of the treatments. 
Table.1 Growth and Root parameters of Macropropagated Banana Suckers

\begin{tabular}{|c|c|c|c|c|c|c|c|c|}
\hline \multirow[t]{2}{*}{ Treatments } & \multicolumn{3}{|c|}{ No. of Suckers } & \multirow{2}{*}{$\begin{array}{l}\text { Height of } \\
\text { pseudostem } \\
(\mathrm{cm})\end{array}$} & \multirow{2}{*}{$\begin{array}{l}\text { No. } 0 \\
\text { Leaves/ } \\
\text { plant }\end{array}$} & \multirow{2}{*}{$\begin{array}{l}\text { Breadth } \\
\text { of Leaves } \\
(\mathrm{cm})\end{array}$} & \multirow{2}{*}{$\begin{array}{l}\text { No. of } \\
\text { Primary } \\
\text { roots }\end{array}$} & \multirow{2}{*}{$\begin{array}{l}\text { Length } \\
\text { of root } \\
(\mathrm{cm})\end{array}$} \\
\hline & Primary & Secondary & Tertiary & & & & & \\
\hline $\mathrm{T}_{1:}$ Control & 2.38 & 3.69 & 15.20 & 22.97 & 5.85 & 15.37 & 18.28 & 36.70 \\
\hline $\mathrm{T}_{2}: T$. viride $(30 \mathrm{~g})$ & 2.58 & 4.22 & 15.79 & 23.30 & 5.67 & 15.85 & 20.33 & 43.79 \\
\hline $\begin{array}{l}\mathrm{T}_{3}: \mathrm{BAP}(0.04 \%)+T \\
\text { viride }(30 \mathrm{~g})\end{array}$ & 3.07 & 5.73 & 18.94 & 21.67 & 5.55 & 16.05 & 23.45 & 42.08 \\
\hline $\mathrm{T}_{4}: \operatorname{BAP}(0.04 \%)$ & 2.94 & 4.82 & 18.40 & 17.17 & 5.87 & 17.18 & 24.72 & 46.56 \\
\hline $\begin{array}{l}\mathrm{T}_{5}: \mathrm{BAP}(0.04 \%)+ \\
\text { Enriched compost }(30 \mathrm{~g})\end{array}$ & 2.83 & 4.53 & 16.02 & 17.60 & 5.77 & 15.68 & 23.61 & 42.30 \\
\hline $\begin{array}{l}\mathrm{T}_{6}: T . \text { viride }(30 \mathrm{~g})+\mathrm{BAP} \\
(0.04 \%)+\text { Enriched } \\
\text { Compost }(30 \mathrm{~g})\end{array}$ & 2.42 & 4.03 & 15.87 & 22.37 & 5.58 & 15.63 & 24.39 & 40.38 \\
\hline $\begin{array}{l}\mathrm{T}_{7}: \text { Azospirillum }(200 \mathrm{~g})+ \\
\text { PSB }(200 \mathrm{~g}) \text { mixed in } 10 \mathrm{~kg} \\
\text { of vermicompost }\end{array}$ & 2.75 & 3.99 & 16.11 & 17.61 & 5.40 & 15.98 & 24.11 & 41.00 \\
\hline $\mathrm{T}_{8}: \mathrm{GA}_{3}(\mathbf{5 0} \mathrm{ppm})$ & 1.00 & 1.8 & 5.23 & 35.67 & 2.98 & 3.30 & 14.33 & 27.76 \\
\hline $\mathrm{T}_{9}:$ IBA $(0.25 \%)$ & 1.82 & 4.12 & 16.94 & 18.69 & 5.50 & 16.11 & 21.50 & 41.44 \\
\hline $\mathrm{T}_{10}$ : Nitrogen $(100 \mathrm{~g} / \mathrm{plant})$ & 1.83 & 4.2 & 16.76 & 19.30 & 5.34 & 16.23 & 18.83 & 37.62 \\
\hline $\mathrm{CD}(\mathrm{P}=0.05)$ & 0.50 & 0.30 & 0.34 & 1.12 & 0.16 & 0.20 & 0.75 & 2.35 \\
\hline
\end{tabular}

Table.2 Economics of production

\begin{tabular}{|c|c|}
\hline Treatments & Benefit: Cost ratio \\
\hline$T_{1}$ (Control) & 2.23 \\
\hline $\mathbf{T}_{2}:($ Trichoderma viride $)$ & 1.82 \\
\hline $\mathrm{T}_{3}:(\mathrm{BAP}+$ Trichoderma viride $)$ & 2.19 \\
\hline $\mathrm{T}_{4}:(\mathrm{BAP})$ & 2.64 \\
\hline $\mathrm{T}_{5}:$ (BAP + Enriched compost) & 2.12 \\
\hline $\mathrm{T}_{6}:$ (T. viride + BAP + Enriched Compost) & 1.63 \\
\hline $\mathrm{T}_{7}:($ Azospirillum + PSB $)$ & 1.56 \\
\hline $\mathrm{T}_{8}:\left(\mathrm{GA}_{3}\right)$ & 0.10 \\
\hline $\mathrm{T}_{9}:($ IBA $)$ & 2.53 \\
\hline $\mathrm{T}_{10}$ : (Nitrogen) & 2.42 \\
\hline
\end{tabular}

The treatments of $\mathrm{T}_{2}$ (Trichoderma viride) and $\mathrm{T}_{9}$ (IBA) produced equal number of leaves (5.62) at the end of hardening of tertiary suckers and they were at par with the leaf number of 5.55 and 5.58 produced by the tertiary suckers treated earlier with $\mathrm{T}_{3}$ (BAP + Trichoderma viride) and $\mathrm{T}_{6}$ (Trichoderma viride $+\mathrm{BAP}+$ Enriched Compost), respectively. It was also observed that there was no significant difference between $\mathrm{T}_{7}$ (Azospirillum $\left.+\mathrm{PSB}\right)$ and $\mathrm{T}_{10}$ (Nitrogen) in production of leaves. The lowest number of leaves (2.98) was recorded in $\mathrm{T}_{8}\left(\mathrm{GA}_{3}\right)$ (Table 1).

Treatments had significant influence on breadth of third leaf both at the beginning and at the end of hardening period. The suckers treated with BAP $\left(\mathrm{T}_{4}\right)$ produced the broadest leaf at the end 
of hardening period $(17.18 \mathrm{~cm})$ and differed significantly from all other treatments. However, variation in breadth of leaf due to the influence of treatments was noted both at the beginning and at the end of hardening period. Of course, the breadth of the leaves of the suckers treated with $\mathrm{GA}_{3}\left(\mathrm{~T}_{9}\right)$ was lowest, i.e. $3.30 \mathrm{~cm}$ at the end of hardening period (Table 1).

Primary roots developed by the tertiary suckers differed significantly due to the different treatments. At the end of hardening, production of primary suckers increased in all the treatments. Tertiary suckers produced significantly highest number of primary roots in $\mathrm{T}_{4}$ (24.72) followed by $\mathrm{T}_{6}$ (24.39) and $\mathrm{T}_{7}$ (24.11).

On the other hand, primary suckers produced by $\mathrm{T}_{5}$ (23.61) and $\mathrm{T}_{3}$ (23.45) were at par with each other and significantly different number of primary roots were produced in $\mathrm{T}_{9}(21.50)$ and $\mathrm{T}_{2}$ (20.33). $\mathrm{GA}_{3}\left(\mathrm{~T}_{8}\right)$ treated suckers produced significantly lowest number of primary roots both before hardening (2.78) and after hardening (14.33) (Table 1).

The length of the longest roots of tertiary suckers measured at the time of hardening significantly increased at the end of hardening. The highest length of roots $(19.00 \mathrm{~cm})$ was found in $\mathrm{T}_{4}$ (BAP) followed by $18.35 \mathrm{~cm}$ in $\mathrm{T}_{2}$ (Trichoderma viride) and $17.87 \mathrm{~cm}$ in $\mathrm{T}_{7}$ (Azospirillum + PSB) which were at par with each other.
At the end of hardening, length of the longest roots increased significantly in the similar trend as observed at the time of hardening. $\mathrm{T}_{4}$ (BAP) recorded the longest $(46.56 \mathrm{~cm})$ roots and differed significantly from the rest of the treatments.

The highest benefit: cost ratio of 2.64 was obtained in $\mathrm{T}_{4}$, i.e., corms treated with BAP $(0.04 \%)$. The lowest benefit: cost ratio (0.10) was calculated out in $\mathrm{T}_{8}$, i.e. corms treated with $\mathrm{GA}_{3}$ (Table 2).

\section{References}

Faturoti, B., Tenkouano, A., Lemchi, J. and Nnaji, N. (2002). Rapid Multiplication of Plantain and Banana: Macropropagation Techniques. A Pictorial Guide. Ibadan, Nigeria: IITA. p. 12.

Panse, V. S. and Sukhatme, P. V. (1985). Statistical method for agriculture workers. ICAR, Pub. New Delhi.

Seshu Reddy, K. V., Ngode, L., Senyonga, J. W., Wabule, M., Onyango, M. and Adede, T. O. (1999). Management of pests and diseases of banana in Kenya: A Status Report. Mobilizing IPM for suitable banana production in Africa. Proceedings of a workshop held in Nelpursuit. INIBAP. Montepellier.

Sheela, V. L. and Ramachandran Nair, S. (2001). Growth, flowering and yield potential of tissue culture banana (Musa AAB cv. Nendran). J. Tropical Agriculture. 39: 1-4.

\section{How to cite this article:}

Dorodi P. Duarah, Subhanakar Saha, D. N. Hazarika, Supriya Langthasa and Rupshree Borah. 2018. Standardization of Suitable Treatment for Sucker Production of Malbhog (AAB) Banana through Macropropagation. Int.J.Curr.Microbiol.App.Sci. 7(05): 3555-3559.

doi: https://doi.org/10.20546/ijcmas.2018.705.410 